\title{
The Philosophy of Mathematics Education
}

\section{Introduction}

This ICME-13 Topical Survey is designed to provide an overview of contemporary research in the philosophy of mathematics education. This is a broad cluster of overlapping but at times disparate themes. In the first instance, this publication exposes some of the problems and questions in mathematics education that the philosophy of mathematics education clarifies, illuminates and sometimes helps to solve. A metaphor for what is offered is a three tier pyramid. At the apex is this publication, presenting an abbreviated 'problematique' of the subfield, that is, the cluster of problems and issues at the heart of the area. At the next level, is the breadth of problems, issues and research results that will be shared when the group of authors of this publication meet with the 'public' at the ICME 13 conference in Hamburg, July 2016. Finally, at the base level is the full spread of research and its results, books, journals, papers, conference presentations and other activities that make up the subfield, the philosophy of mathematics education, which is beyond the scope of this publication and conference. This publication thus briefly sketches some of the topics, problems and areas of active research (the apex) and through this point to some of what will be offered at the conference (the middle level). In doing so it serves as an introduction to the extent of the sub-field overall, through references to current publications and classic literature (the base of the pyramid).

Why the philosophy of mathematics education? What does it offer? The philosophy of any activity comprises its aims or rationale. Given our shared commitment to the teaching and learning of mathematics it is vital ask: What is the purpose of teaching and learning mathematics? What do we value in mathematics and its teaching and learning? Why do we engage in these practices and what do we 
hope will be achieved? The sub-field can also help us uncover whatever implicit assumptions and priorities underlie mathematics education. These can including paradigmatic assumptions of which we may be unaware, but that can be identified through, let us say, a philosophical archaeology.

The philosophy of mathematics education applies philosophical methods to a critical examination of the assumptions, reasoning and conclusions of mathematics education, systematically enquiring into fundamental questions:

- What is mathematics?

- How does mathematics relate to society?

- Why teach mathematics?

- What is the nature of learning (mathematics)?

- What is the nature of mathematics teaching?

- What is the significance of information and communication technology in the teaching and learning of mathematics?

- What values underlie these activities, overt and covert?

- How and to what extent is social justice promulgated by these activities and this field of study?

- What is the status of mathematics education as knowledge field?

- What deep and often unacknowledged assumptions underlie mathematics education research and practice?

The philosophy of mathematics education matters because it gives people new 'glasses' through which to see the world. It enables people to see beyond official stories about the society, mathematics, and education. It provides thinking tools for questioning the status quo, for seeing 'what is' is not what 'has to be'; enabling us to imagine alternatives possibilities.

In addition to laying out the conceptual traditions and 'problematique' of the philosophy of mathematics education, this topical survey also presents a case study of research in the topic conducted in one country. As will emerge in all of the sections, Brazil has played a strong role in the formation and development of philosophy of mathematics education research, especially in the connected and well-known areas of critical mathematics education and ethnomathematics (see, for example, D'Ambrosio 1985, 1998, 2006). In addition to these special interests Brazil has an active research community in the theoretical aspects of the philosophy of mathematics education and their applications to policy and practice. Recent developments in terms of organisation, basis and research orientation of one strand in the area are sketched in Sect. 5. 


\section{An Overview of the Philosophy of Mathematics Education}

\section{Paul Ernest}

\subsection{Introduction: What Is the Philosophy of Mathematics Education?}

The philosophy of mathematics education can be interpreted both narrowly and more widely. Understood narrowly the philosophy of some activity is its aim or rationale. So in the narrow sense the philosophy of mathematics education concerns the aims or rationale behind the practice of teaching mathematics. However, the aims, goals, purposes, rationales, etc., for teaching mathematics do not exist in a vacuum, belonging to people, whether individuals or social groups (Ernest 1991). Since the teaching of mathematics is a widespread and highly organised social activity, its aims, goals, purposes, rationales, and so on, need to be related to social groups and society in general, while acknowledging that there are multiple and divergent aims and goals among different persons and groups. Aims are expressions of values, and thus the educational and social values of society or some part of it are implicated in this enquiry.

There are broader interpretations of that go beyond the aims, rationale and basis for teaching mathematics. Expanded senses of the philosophy of mathematics education include:

1. Philosophy applied to or of mathematics education

2. Philosophy of mathematics applied to mathematics education or to education in general

3. Philosophy of education applied to mathematics education (Brown 1995).

Each of these possible applications of philosophy to mathematics education represents a different focus, and might very well foreground different issues and problems. However, these of applications of philosophy involve substantive bodies of knowledge. In fact, philosophy, mathematics education and other domains of knowledge encompass processes of enquiry and practice, personal knowledge, and as well as published knowledge representations. They are not simply substantial entities in themselves, but complex relationships and interactions between persons, society, social structures, knowledge representations and communicative and other practices. Thus a further expanded sense of the philosophy of mathematics education includes the applications of philosophical processes, methods and critical modes of thought. 
4. The application of philosophical concepts or methods, such as a critical attitude to claims as well as detailed conceptual analyses of the concepts, theories, methodology or results of mathematics education research, and of mathematics itself (Ernest 1998; Skovsmose 1994).

Philosophy is about systematic analysis and the critical examination of fundamental problems. It involves the exercise of the mind and intellect, including thought, enquiry, reasoning and its results: judgements, conclusions, beliefs and knowledge. There are many ways in which such processes as well as the substantive theories, concepts and results of past enquiry can be applied to and within mathematics education.

Why does philosophy matter? Why does theory in general matter? First, because it helps to structure research and inquiries in an intelligent and well grounded way, offering a secure basis for knowledge. It provides an overall structure fitting the results of cutting edge research into the hard-won body of accepted knowledge. But in addition, it enables people to see beyond the official stories about the world, about society, economics, education, mathematics, teaching and learning. It provides thinking tools for questioning the status quo, for seeing that 'what is' is not 'what has to be'; to see that the boundaries between the possible and impossible are not always where we are told they are. It enables commonly accepted notions to be probed, questioned and implicit assumptions, ideological distortions or unintended prejudices to be revealed and challenged. It also, most importantly, enables us to imagine alternatives. Just as literature can allow us to stand in other people's shoes and see the world through their eyes and imaginations, so too philosophy and theory can give people new 'pairs of glasses' through which to see the world and its institutional practices anew, including the practices of teaching and learning mathematics, as well as those of research in mathematics education.

This analysis suggests that the philosophy of mathematics education should attend not only to the aims and purposes of the teaching and learning of mathematics (the narrow sense) or even just the philosophy of mathematics and its implications for educational practice. It suggests that we should look more widely for philosophical and theoretical tools for understanding all aspects of the teaching and learning of mathematics and its milieu. At the very least we need to look to the philosophy of Schwab's (1961) commonplaces of teaching: the subject, learner, teacher, and the milieu or society. So we also have as areas of interest and concern the philosophy of learning (mathematics), the philosophy of teaching (mathematics) and the philosophy of the milieu or society (in the first instance with respect to mathematics and mathematics education) and we should also consider the discipline of mathematics education as a knowledge field in itself, its 'nature' and status.

Looking at each of these four commonplaces, a number of big questions can be posed as issues for the philosophy of mathematics education to address, including 
the following, each of which can be expanded to many sub questions, as I do below, with question 5 (I expand the others in Ernest 2014).

1. What is mathematics?

2. How does mathematics relate to society?

3. What is learning (mathematics)?

4. What is teaching (mathematics)?

5. What is the status of mathematics education as knowledge field?

The last questions mathematics education itself. Is mathematics education a discipline, a field of enquiry, an interdisciplinary area, a domain of extra-disciplinary applications, or what? Is it a science, social science, art or humanity, or none or all of these? What is its relationship with other disciplines such as philosophy, mathematics, sociology, psychology, linguistics, anthropology, etc.? How do we come to know in mathematics education? What is the basis for knowledge claims in research in mathematics education? What research methods and methodologies are employed and what is their philosophical basis and status? How does the mathematics education research community judge knowledge claims? What standards are applied? How do these relate to the standards used in research in general education, social sciences, humanities, arts, mathematics, the physical sciences and applied sciences such as medicine, engineering and technology? What is the role and function of the researcher in mathematics education? What is the status of theories in mathematics education? Do we appropriate theories and concepts from other disciplines or 'grow our own'? Which is better? What impact on mathematics education have modern developments in philosophy had, including phenomenology, critical theory, post-structuralism, post-modernism, Hermeneutics, semiotics, linguistic philosophy, etc.? What is the impact of research in mathematics education on other disciplines? What do adjacent STEM education subjects (science, technology, engineering and mathematics education) have in common, and how do they differ? Can the philosophy of mathematics education have any impact on the practices of teaching and learning of mathematics, on research in mathematics education, or on other disciplines? What is the status of the philosophy of mathematics education itself? How central is mathematics to research in mathematics education? Does mathematics education have an adequate and suitable philosophy of technology in order to accommodate the deep issues raised by information and communication technologies?

These five questions encompass much of what is important for the philosophy of mathematics education to consider and explore. These sets are not wholly discrete, as various areas of overlap would be revealed. Many of the sub-questions involved (omitted here except for question 5, but see Ernest 2014) are not essentially philosophical, in that they can also be addressed and explored in ways that foreground other disciplinary perspectives, such as sociology and psychology. However, when such questions are approached philosophically, they become part of the business of the philosophy of mathematics education. Also, the philosophy of 
mathematics education is an area where interdisciplinary questions can be addressed and tentative answers explored. Lastly, if there were a move to exclude any of these questions right from the outset without considering them it would risk adopting or promoting a particular philosophical position, a particular ideology or philosophy of mathematics education. Exclusionary tactics across social and conceptual domains often have an unacknowledged hidden agenda, and mostly do not serve the advance of knowledge.

\subsection{A 'Top Down' Analysis of the Philosophy of Mathematics Education}

The above five questions and their concomitant sub-questions might be taken to represent a 'bottom up' introduction to the philosophy in mathematics education, because they start with, interrogate and problematise the practices of teaching and learning mathematics and related issues. A 'top down' approach might use instead the abstract branches of philosophy to provide the conceptual framework for analysis. Thus it could consider research and theory in mathematics education according to whether it draws on ontology and metaphysics; epistemology and learning theory; social and political philosophy; aesthetics, ethics and axiology (the philosophy of values) more generally; the methodology of mathematics education research; or other branches of philosophy. Ontology and metaphysics have as yet been little applied in mathematics education research (Ernest 2012). Work drawing on aesthetics is still in its infancy (Ernest 2013, 2015; Sinclair 2008). However extensive uses of epistemology and learning theory, social and political philosophy, ethics and methodology can be found in mathematics education research and literature.

In addition to the contributions of the substantive branches of philosophy to mathematics education, there are also benefits to be gained from applying philosophical styles of thinking in our research. For example, many of the constructs we utilise need careful conceptual analysis and critique. I have in mind such widely used ideas as understanding, development, progress, progressivism, mathematical ability, nature/natural, cultural/artificial, values, objectivity/subjectivity, identity, working like a mathematician, learning, discovery learning, problem solving (including pure, applied, 'real' and 'authentic' problems), teaching, assessment, mathematics, knowledge, sex/gender, special needs in mathematics, multiculturalism/antiracism, ethnomathematics, context, both social and task-related, and so on.

Understanding is perhaps the most basic and obvious of these terms, so what can deconstructing it add to our knowledge? Can it contain hidden assumptions and pitfalls? First of all, it is based on the peculiar metaphor of 'standing under'. In what way does this capture its meaning? Synonyms like 'grasping', 'getting a handle on' or 'seeing' it are all based on familiarity through a sensory encounter with meaning, 
and on being able to control or possess it ('getting it'). Thus these metaphors presuppose a static 'banking' model, interpreting understanding as the acquisition, ownership or possession of knowledge (Sfard 1998). But secondly, there is an ideological assumption that understanding a concept or skill is better, deeper and more valuable than simply being able to use or perform it successfully. Skemp (1976) distinguished 'relational understanding' from 'instrumental understanding', and posited the superiority of the former. However his co-originator of the distinction Mellin-Olsen (1981) used it to distinguish the modes of thinking of academic students from that of apprentices, thus bringing in a social context and even a social class dimension to the distinction, and imposing less of an implicit received valuation. If we want to assert the superiority of relational understanding over instrumental understanding it needs to be done on the basis of a reasoned argument, and not taken for granted as obvious. Skemp's own argument was based on the psychology of schemata, based on Piagetian theories, but this have been challenged by a number of alternate theories of learning including socio-cultural theory and social constructivism, drawing on Vygotsky's theory of learning. According to Vygotsky knowledge is not something that the learner possesses but is a competence inferred from the learner's manifested ability to complete a task, either unaided, or, with the help of a more capable other, in what is termed the learner's zone of proximal development. Given current challenges to the underlying theories of learning, the assumption that relational understanding is superior stands in need of justification.

Some scholars have challenged the unquestioned pre-eminence of relational understanding. Hossain et al. (2013) question the accepted good of the related notion of 'understanding mathematics in-depth' because, as they show, its role in the identity work of some student-teachers is troubling to them. ${ }^{1}$ for example, one student teacher with the pseudonym Lola experiences a conflict between the imposed good of relational understanding, when studying England, and her own success within the norms of instrumental understanding that she internalized in her Nigerian upbringing (Ernest in press). Others have challenged the uncritical promotion of understanding within the mathematics education community because of its incoherence. Llewellyn (2010) questions 'understanding' partly because of slippage in the use of the term so that it encompasses both its relational and instrumental forms. However, her deeper critique is that in use it carries with a whole host of problematic assumptions about who can own 'understanding' in terms of ability, gender, race, class.

Understanding is produced as hierarchical, particularly in relation to gender, social class and ability. It belongs to the privileged few, the 'naturally' able, which are often boys (another unhelpful and unnecessary classification). To suggest that girls have a 'quest for understanding' is over simplistic and gendered and in the first instance we should unpack how each version of understanding is constructed. ... Finally I suggest that student teachers

\footnotetext{
${ }^{1}$ In later work Skemp (1982) refers to instrumental understanding as 'surface' and relational understanding as 'deep' understanding, thus prefiguring the depth metaphor in the more recently coined term 'understanding mathematics in-depth'.
} 
do not produce understanding as cognitive; the child is not an automaton who performs as the government text prescribes. Pupils and understanding are tied up with notions such as gender, confidence and emotions. (Llewellyn 2010, pp. 355-356)

Although what I have offered here is not conclusive, what the example shows is that even a widely presupposed good in the discourse of mathematics education, the concept of understanding, is a worthwhile target of philosophical analysis and critique. Although such analysis does not mean that we have to abandon the concept, it does mean that we need to be aware of the penumbra of meanings revealed and aporias unleashed through its deconstruction. We need to use the term with caution and precision, clarifying or sidestepping its troubling connotations and implications. Thus the philosophy of mathematics education, as well as offering valuable overarching and synoptic views and explanations of our field, also serves as an under-labourer "in clearing the ground a little, and removing some of the rubbish that lies in the way to knowledge" (Locke 1975, p. 10). It can clear the conceptual landscape of unnoticed obstacles and perform the hygienic function of targeting, inoculating and neutralizing potentially toxic ideas circulating, like viruses, in our discourse.

\subsection{Conclusion}

In Sect. 2 I have sketched one vision of what the philosophy of mathematics education might be. However, this little assay into the topic is just the beginning, for there are many more unanswered questions. For example: what are the overall responsibilities of mathematics education as an overall field of study and practice, and what is the responsibility of our own subfield, the philosophy of mathematics education? What are the responsibilities of mathematics education researchers? Does this depend on our philosophical stances, whether we see ourselves as critical public intellectuals or as functional academics probing deeper into narrow specialisms?

Philosophy emerged from the dialectics of the ancient Greeks where commonplace beliefs and unanalysed concepts were interrogated and scrutinised, where the role of the rulers was questioned and challenged through speaking truth to power. Thus the role of the philosophy of mathematics education is to analyse, question, challenge, and critique the claims of mathematics education practice, policy and research. Our job is to unearth hidden assumptions and presuppositions, and by making them overt and visible, to enable researchers and practitioners to boldly go beyond their own self-imposed limits, beyond the unquestioned conceptual boundaries installed by the discourse of our field, to work towards realizing their own dreams, visions and ideals. 


\section{Critical Mathematics Education: Concerns, Notions, and Future ${ }^{2}$}

\section{Ole Skovsmose}

Critical mathematics education works for social justice in whatever form possible, and it addresses mathematics critically in all its appearances and applications.

It has developed in many directions, and as a consequence the very notion of critical mathematics education refers to a broad range of approaches. One can think of mathematics education for social justice (Sriraman 2008; Wager and Stinson 2012); pedagogy of dialogue and conflict (Vithal 2003); radical mathematics (Frankenstein 1989); responsive mathematics education (Greer et al. 2009); and criticalmathematics education (Frankenstein 1989, 2012; Powell 2012). Many ethnomathematical studies also link closely with critical mathematics education (D’Ambrosio 2006; Knijnik 1996; Powell and Frankenstein 1997). Explicit formulations of critical mathematics education are found in, for instance, Frankenstein (1983) and Skovsmose (1994, 2011a).

\subsection{Some Concerns in Critical Mathematics Education}

Critical mathematics education can be characterised in terms of concerns, and let me mention some related to mathematics, students, teachers, and society.

Mathematics can be brought in action in technology, production, automatisation, decision making, management, economic transaction, daily routines, information procession, communication, security procedures, etc. In fact mathematics in action plays a part in all spheres of life. It is a concern of a critical mathematics education to address mathematics in its very many different forms of applications and practices. There are no qualities - like, for instance, objectivity and neutrality - that automatically can be associated to mathematics. Mathematics-based actions can have all kind of qualities, being risky, reliable, dangerous, suspicious, misleading, expensive, brutal, benevolent, profit-generating, etc. Mathematics-based action can serve any kind of interest. As with any form of action, so also mathematics in action is in need of being carefully criticized. This applies to any form of mathematics: everyday mathematics, engineering mathematics, academic mathematics, as well as ethnomathematics (see, for instance, Skovsmose 2012, 2015a, c; Yasukawa et al. 2015).

Students. To a critical mathematics education it is important to consider students' interests, expectations, hopes, and aspirations. Thus Frankenstein (2012) emphasises the importance of respecting student knowledge. The notion of students'

\footnotetext{
${ }^{2}$ This text is a revised version of my entry "Critical Mathematics Education" in Lerman (2014), pp. 116-120. I thank the editor for his kind permission to use it here.
} 
foregrounds has been suggested in order to conceptualise students' perspectives and interests (see, for instance, Skovsmose 2014a). A foreground is defined through very many parameters having to do with: economic conditions, social-economic processes of inclusion and exclusion, cultural values and traditions, public discourses, racism. However, a foreground is, as well, defined through the person's experiences of possibilities and obstructions. It is a preoccupation of critical mathematics education to acknowledge the variety of students' foregrounds, and to develop a mathematics education that might provide new possibilities for the students. This concern is, for instance, expressed through an intentionalityinterpretation of meaning (Skovsmose 2015b).

Teachers. As it is important to consider the students' interests, it is important to consider the teachers' interests and working conditions as well. Taken more generally, educational systems are structured by the most complex sets of regulations, traditions, restrictions, which one can refer to as the "logic of schooling". This "logic" reflects the economic order of today, and to a certain degree it determines what can take place in the classroom. It forms the teachers' working conditions. It becomes important to consider the space of possibilities that might be left open by this logic. These considerations have to do with the micro-macro (classroomsociety) analyses as in particular addressed by Paola Valero (see, for instance, Valero 2009). Naturally, these comments apply not only to the teachers' working conditions but also to the students' conditions for learning.

Society can be changed. This is the most general claim made in politics. It is the explicit claim of any activism. And it is as well a concern of critical mathematics education. Following Freire's formulations, Gutstein (2006) emphasises that one can develop a mathematics education which makes it possible for students to come to read and write the world: "read it", in the sense that it becomes possible to interpret the world filled with numbers, diagrams, and figures; and "write it", in the sense that it becomes possible to make changes. However, a warning has been formulated: one cannot talk about making socio-political changes without acknowledge the conditions for making changes (see, for instance, Pais 2012). Thus the logic of schooling could obstruct many aspirations of critical mathematics education. Anyway, I find that it makes good sense to articulate a mathematics education for social justice, not least in a most unjust society.

\subsection{Some Notions in Critical Mathematics Education}

Notions such as social justice, mathemacy, dialogue, pedagogical imagination, and uncertainty are important for formulating concerns of critical mathematics education.

Social justice. Critical mathematics education includes a concern for addressing any form of suppression and exploitation. As already indicated, there is no guarantee that an educational approach might in fact be successful in bringing about any justice. Still, working for social justice is a principal concern of critical mathematics 
education. Naturally, it needs to be recognised that "social justice" is an open concept, the meaning of which can be explored in many different directions. Addressing equity also represents concerns of critical mathematics education, and the discussion of social justice and equity bring us to address processes of inclusion and exclusion. Social exclusion can take the most brutal forms being based on violent discourses expressing racism, sexism, and hostility towards "foreigners" or "immigrants". Such discourses might label groups of people as being "disposable", "a burden", or "non-productive", given the economic order of today. It is a concern of critical mathematics education to address any form of social exclusion (see, for instance, Martin 2009). However, social inclusion might also represent a questionable process: it could mean an inclusion into the capitalist mode of production and consumption. So, critical mathematics education needs to address inclusion-exclusion as contested processes. However, many forms of inclusion-exclusion have until now not been discussed profoundly in mathematics education: the conditions of blind students, deaf students, students with different disabilities - in other words: students with particular rights. However, such issues are now being addressed in the research environment created by the Lulu Healy and Miriam Goody Penteado in Brazil. Such initiatives bring new dimensions to critical mathematics education.

Mathemacy is closely related to literacy, as formulated by Freire, being a competence in reading and writing the world. Thus, D'Ambrosio (1998) has presented a "New Trivium for the Era of Technology" in terms of literacy, matheracy and technoracy. (D'Ambrosio talks about matheracy, while I prefer to use mathemacy.) Chronaki (2010) provides a multifaceted interpretation of mathemacy, and in this way it is emphasised that this concept needs to be re-worked, re-interpreted, and re-developed in a never-ending process. Different other notions have, however, been used as well for these complex competences, including mathematical literacy and mathematical agency. Jablonka (2003) provides a clarifying presentation of mathematical literacy, showing how this very notion plays a part in different discourses, including some that hardly represent critical mathematics education. The notion of mathematical agency helps to emphasise the importance of developing a capacity not only with respect to understanding and reflection but also with respect to acting.

Dialogue. Not least due to the inspiration from Freire, the notion of dialogue has played an important role in the formulation of critical mathematics education. Dialogic teaching and learning has been presented as one way of developing broader critical competences related to mathematics (see Alrø and Skovsmose 2002). Dialogic teaching and learning concerns forms of interaction in the classroom. It can be seen as an attempt to break at least some features of the logic of schooling and as a way of establishing conditions for developing mathemacy (or mathematical literacy, or mathematical agency). Problem-based learning and project work can also be seen as way of framing a dialogic teaching and learning.

Pedagogical imagination. Critique in terms of imagination has been formulated in terms of sociological imagination. Through such imagination one reveals that something being the case could be different. I find that a pedagogical imagination 
makes part of a critical educational endeavour. Such an imagination helps to show that alternative can be explored and that different possibilities might be within reach. I find that researching possibilities makes integral part of a critical mathematics education (see, Skovsmose 2009b, 2011b; Skovsmose and Penteado 2015).

Uncertainty. Critique cannot be any dogmatic exercise, in the sense that it can be based on any well-defined foundation. One cannot take as given any particular theoretical basis for critical mathematics education; it is always in need of critique (see, for instance, Ernest 2010). In particular one cannot assume any specific interpretation of social justice, mathemacy, dialogue, etc. They are all contested concepts. They are under construction. The open nature of critical mathematics education is further emphasised by the fact that forms of exploitations, suppressions, environmental problems, critical situations in general are continuously changing. Critique cannot develop according to any pre-set programme. As a consequence, the basic epistemic condition for a critical activity is uncertainty (see, Skovsmose 2009a, 2014b).

\subsection{Critical Mathematics Education for the Future}

Recent developments of critical mathematics education are, for instance, formulated in Alrø et al. (2010), Ernest et al. (2015) and Skovsmose and Greer (2012).

Looking into the future much more is on its way. Let me just refer to some doctoral studies in progress that I am familiar with. Ana Carolina Faustino addresses dialogical processes in primary mathematics education. Not least inspired by the work of Freire, dialogic education has developed with many references to adult education. However, Faustino is going to rework the very conception of dialogue with particular reference to younger children. Amanda Queiroz Moura investigates mathematics education for deaf students. This brings her to address particular aspects of inclusive education as well as of dialogical education, and in this way to provide new dimensions to the discussion for mathematics education for social justice. João Luiz Muzinatti works with middle class students, and through different mathematical projects he is challenging a range of assumptions and preconceptions that dominate middle class discourses. Thus Muzinatti formulates new concerns of critical mathematics education. Guilherme Henrique Gomes da Silva addresses affirmative actions. He investigates the different components of such actions, emphasising that affirmative actions also must address the very educational format of university studies. This way da Silva brings a new specificity to the discussion of affirmative actions.

We always have to remember that much research in mathematics education is not presented in English, but in other languages. The same applies to critical mathematics education. Here one finds important contribution in Portuguese as, for instance, Biotto Filho (2015), Marcone (2015) and Milani (2015). (See also, Skovsmose 2001, 2007, 2008; Valero and Skovsmose 2012.) 
Critical mathematics education is an on-going endeavour. And naturally we have to remember that as well the very notion of critical mathematics education is contested. There are very many different educational endeavours that address critical issues in mathematics education that do not explicitly refer to critical mathematics education. And this is exactly as it should be as the concerns of critical mathematics cannot be limited by choice of terminology.

\section{The Philosophy of Mathematical Practice: What Is It All About? ${ }^{3}$}

\section{Jean Paul Van Bendegem}

\subsection{Lakatos as the Starting Point}

Taking into account that almost any historical outline is partially a reconstruction, one wants nevertheless to find a historical starting or turning point of a sufficiently symbolic nature. Or, if you like, if the philosophy of mathematics underwent a similar change as the one that "shook" the philosophy of science (at least, according to some), then it seems fair ${ }^{4}$ to take Lakatos (1976) seminal Proofs and Refutations, a work that was in part inspired by Pólya's (1945) How to Solve It which discusses heuristics and problem-solving techniques in an educational setting. Its focus on mathematical practice was clear by the mere fact that it boldly presented nothing less than a "logic" of mathematical discovery. What did the book offer? Nothing less but the history of a mathematical statement and its proofs. That fact alone should amaze everybody for is not mathematics supposed to be timeless, eternal even, unchangeable for sure and is mathematical proof not supposed to be absolutely certain, undoubtable, secure? This implies that, if a proof is found for a statement A, then A has been proven and that is that. To which is usually added: and a wrong proof is not a proof, it is just wrong. Lakatos disagrees and takes as an example the statement that for polyhedra (in three-dimensional Euclidean space), $\mathrm{V}($ ertices $)-\mathrm{E}($ dges $)+\mathrm{F}($ aces $)=2$. Take, e.g., a cube. There are 8 vertices, 12 edges and 6 faces and indeed $8-12+6=2$. Euler himself had found an ingenious proof or so he believed. As soon as the proof was around, counterexamples appeared, making it necessary to (sometimes seriously) modify the proof and, in

\footnotetext{
${ }^{3}$ This paper is a reduced version of Van Bendegem (2014), corresponding to a summary of its first part. In its second part I examine the relations between the study of mathematical practices and foundational studies of mathematics.

4'Fair' does not necessarily mean historically balanced. A more complete history should deal with the French historico-philosophical approach to mathematics, including such thinkers as Léon Brunschvicg and his pupils Albert Lautman and Jean Cavaillès.
} 
that sense, the proof has a history. Even more importantly is that Lakatos found patterns in this game of proof and refutation, explaining thereby the title of the book. In this book, writing in a dialogue form, stressing the dynamics of the search for a 'final' proof, a totally different picture was drawn of what mathematics is and what it is about.

\subsection{Kitcher as the Next Step}

There was not an immediate follow-up, as far as I can see, on Lakatos' ideas. We had to wait until 1983, when Kitcher (1983) proposed in his book The Nature of Mathematical Knowledge, a more or less formal model of how mathematics as an activity can be described, clearly inspired by the developments in the philosophy of science, where attempts to develop formal models have always been present. It is sufficient to think of the logico-mathematical work of Sneed (1971), formalizing a Kuhnian outlook, as a prime example. However Kitcher's approach is definitely not a continuation of what Lakatos had initiated. For one thing, Kitcher discusses philosophical problems that clearly belong to the traditional philosophy of mathematics, such as questions of realism, of the existence of mathematical objects, of our capability (or lack of it) to get to know these objects, and so forth. In short, in Kitcher's approach we get a mixture of the more radical Lakatosian view and more traditional philosophy of mathematics, using a Kuhnian framework to accommodate both. The Kitcherian outlook proved to be more successful, as several authors embraced this trend, as is shown in subsequent volumes that made connections between philosophy and history of mathematics, witness Tymoczko (1986) and Aspray and Kitcher (1988). ${ }^{5}$

\subsection{A Tension Is Introduced to Stay}

This initial tension between Lakatos and Kitcher has never left (up to now) the study of mathematics through its practices. The nature of that tension is anything but new. We have known it in the philosophy of science in the form of the context of discovery versus context of justification divide. A justification is preferably seen as something independent from the discovery process. In other words, if I need to justify something, I need not wonder about how it is has been found. In the case of mathematics, if such an independence holds, then I only need to look at the finished proof, the final version and wonder whether or not I can justify that this text that claims to be a proof, indeed is a proof. The processes that led to the proof are of no

\footnotetext{
${ }^{5}$ Of course all contributions by historians of mathematics should be mentioned here but that would double the length of this paper.
} 
importance. Lakatos' claim is exactly the opposite: to make sense of how mathematics develops, an understanding of these discovery processes is essential. Kitcher is prepared not to defend the totally independence view but is willing to allow such elements from the practices that are necessary to understand the final results, in most case, the proofs. All this means that, right from the start, two approaches were being initiated and developed. Has the situation changed much since then? To be honest, not that much.

Mancosu (2008, p. 3) identifies two main traditions within this new research "paradigm", the study of mathematical practices. The first is, what he calls, the 'maverick' tradition which remains close(r) to the Lakatosian approach, ${ }^{6}$ while the second one settles itself within the modern analytical tradition, thus remaining closer to Kitcher than to Lakatos, and focuses, among other things, on the naturalizing programme that started with Willard V.O. Quine, and where, e.g., Maddy (1997), has played and still plays an important role. However within this analytical tradition two approaches can be identified. As an example, think of proofs that involve the use of computers. How to study this phenomenon? At least two attitudes are possible: either ask the mathematicians and if they tell you that they consider it to be a proof, that is what should be reported, together with the reasons and arguments why they believe so, or make a study of the nature of such proofs, how mathematicians handle them and establish whether they can be considered to be genuine proofs and, if not, report back to the mathematicians that they have a problem. The former is more descriptive whereas the latter is more normative. All this means that we can identify three major approaches in the philosophy of mathematical practice:

(a) The Lakatosian approach, also called the 'maverick' tradition,

(b) The descriptive analytical naturalizing approach,

(c) The normative analytical naturalizing approach.

This, however, is absolutely not the end of the story.

\subsection{Enter the Sociologists, Educationalists and Ethnomathematicians}

One might be amazed by the fact that I did not explicitly include historians in this section's title. The obvious answer, I believe, is that they do not need to enter for they are already inside (and for quite some time for that matter). In other words, there are well established connections between mathematics, the history of mathematics and the philosophy of mathematics.

Independently of these developments in the philosophy of mathematics, but also partially inspired by Lakatos as well as Thomas Kuhn, some researchers developed

\footnotetext{
${ }^{6}$ The author of this paper is supposed to belong to this tradition and I do most certainly not object!
} 
a sociology of mathematics, where one of the major focuses was mathematical practice as a group or community phenomenon. Two works should be mentioned in this line: Bloor's (1976) Knowledge and Social Imagery and Restivo's (1985) The Social Relations of Physics, Mysticism, and Mathematics. In contrast with history and philosophy of mathematics, the sociological approach did not merge easily with the mentioned traditions, see, e.g., Restivo et al. (1993). Plenty of reasons can be listed but surely one of the corner elements is the internal-external debate, yet another tension to be introduced in the framework: does mathematics develop according to 'laws' or patterns that are internal to mathematics (and, as a consequence, independent or at least marginally influenced at most by external 'laws' or patterns), or, on the contrary, do external elements contribute and, if so, in what way $(\mathrm{s})$ ?

One outcome of these discussions has been to draw the attention to other, so far neglected, areas where mathematics is involved, prominently mathematics education and ethnomathematics. To avoid all misunderstandings, I do not mean, of course, that these domains did not exist before the practice turn in the philosophy of mathematics, witness on the one hand the pioneering work ${ }^{7}$ of Pólya, that has already been mentioned, and, on the other hand, the equally pioneering work of Ubiratan D'Ambrosio. ${ }^{8}$ Quite the opposite but they were not perceived as being relevant to the philosophy of mathematics. In the standard view, mathematics educators are interested in how pupils can learn to grasp the concept of a mathematical proof or the certainty involved in a geometric construction or develop the ability to translate a verbal problem into a mathematical problem. That, of course, had little or nothing to do with questions such as what are reliable foundations for the whole of mathematics and is set theory a better or worse candidate than category theory (to name the two, rather unequal, rivals at the present moment). In that very same standard view, ethnomathematics is a branch of anthropology and, as such, not relevant to a study of a high-level abstract mathematical problem in western mathematics.

From the practice point of view, however, the links are evident. Firstly, practices are "carried" by people and people have to be educated, that forges the link with education, and, secondly, practices are socially embedded and thus culturally situated, that forges the link with ethnomathematics. Or, if you like, educations concerns the diachronic dimension of how mathematical knowledge is situated in time, whereas ethnomathematics concerns the synchronic dimension of how mathematical knowledge is situated in space. Finally, it must be added that mathematics education and ethnomathematics have an extensive, non-empty intersection.

And still the picture is not complete.

\footnotetext{
${ }^{7}$ Today one of the core figures in the field is Bishop (1988). See also François and Van Bendegem (2007).

${ }^{8}$ Although the first time the concept is mentioned in a paper is 1985, see D'Ambrosio (1985), informally the term was circulating much earlier and even in the 1985 paper it is clear that the Lakatos approach did not play a role.
} 


\subsection{Brain and Cognition Complete the Picture}

Other sciences play a part as well and I just mention the two most important ones, namely (evolutionary) biology and (cognitive) psychology. In the first field, the challenge is to determine how much mathematical knowledge is biologically, perhaps genetically, encoded in the human body and how it affects our mathematical abilities. The work of, e.g., Stanislas Dehaene, see Dehaene and Brannon (2011) for an excellent overview, is the best illustration of this type of work. It involves as well comparisons between humans and other animals, leading, by the way, to quite intriguing results such as the fact that basic mathematical capabilities are definitely not exclusively human. In the second field, one of the main topics is the study of human thinking and, quite trivially, since mathematical thinking is a perhaps highly particular and extraordinary form of thinking, it should and does attract their attention. What immediately comes to mind is the well-known study of Lakoff and Núñez (2000). And, to further increase the complexity, these studies can range from brain activity studies of mathematical tasks human subjects have to perform, to interviews with mathematicians on the way they (think they) solve mathematical problems.

We did already identify three major approaches in the philosophy of mathematical practice to which five approaches need to be added:

(a) The Lakatosian approach, also called the 'maverick' tradition,

(b) The descriptive analytical naturalizing approach,

(c) The normative analytical naturalizing approach,

(d) The sociology of mathematics approach,

(e) The mathematics educationalist approach,

(f) The ethnomathematical approach,

(g) The evolutionary biology of mathematics,

(h) The cognitive psychology of mathematics.

A complex picture indeed!

\subsection{Conclusion: Working in Different "Registers"}

One of the major consequences of the complexity of this situation as sketched above, is that, as a philosopher-mathematician myself, I find that I have to work in different "registers" when reading different texts in the field (or that I, at least, consider to be relevant). There is a world of difference reading papers (a) on representations of numbers in the brain, or (b) on a cognitive-analytical approach to the use of diagrams in mathematical reasoning, where the thought processes are described in detail, or, (c) on a sociological analysis of the mathematical concepts of space and time, where anthropological methodologies are of crucial importance to be aware of possible cultural biases, or, finally, (d) a formal approach to what explanatory strength of proofs could be. 
Let there be no mistake: one might think that perhaps we are dealing here with a division of labour of a vast field to explore, but such a division suggests that all the parts can be put together again to form a minimally coherent whole. And that is (at present) definitely not the case. There are, as I have indicated, fundamental oppositions and tensions at play. Therefore, it follows, I believe, that the two major tasks for the future are, first, to develop a greater coherence in the field and, two, to keep the conversation going with the other philosophers of mathematics (that so far have not been mentioned). ${ }^{9}$

\section{The Philosophy of Mathematics Education in Brazil}

\section{Maria Aparecida Viggiani Bicudo and Roger Miarka}

In this section we present a case study: the range of systematic work in philosophy of mathematics education that has been conducted in Brazil. We have chosen Brazil for our case study because this is a country very active in this area of research. Sections 3 and 4 have already pointed to some of the important historical contributions by Brazilian researchers to the field. One need only mention the work of D'Ambrosio $(1985,1998,2006)$ to indicate the international significance of work done here. In addition, because of the strong links with Brazil among our authors, we are able to draw on special knowledge of recent developments and progress in this area of research. The particular strand of work in the area that we will describe here started at the end of the 1980s in the Graduate Program in Mathematical Education of UNESP in Rio Claro, with masters and doctoral theses that assumed a phenomenological philosophy as background, based mainly on the work of Edmund Husserl. In addition, this phenomenological conception also supported the development of the qualitative research approach and further research on the philosophy of mathematics education developed in this program drawing on other backgrounds. Thus the philosophy of mathematics education research in Brazil within this particular strand works with the hermeneutics of texts, with analyses of pedagogical practices, producing essays that reveal philosophical ideas, articulating them with opportunities to do Mathematics Education in a future time, as well as with the analysis of developing public policies in education.

From the beginning the work produced by Michael Otte and his colleagues of Bielefeld was very important. In the decade of 1990s, the work of Paul Ernest was important for the adoption of the name 'the philosophy of mathematics education' for this area of work. Gradually interest on this theme grew and gained recognition

\footnotetext{
${ }^{9}$ A short historical note: in 2002 a conference was organized in Brussels, Belgium, where the organizers, Jean Paul Van Bendegem and Bart Van Kerkhove, tried to realize their ambition in bringing together representatives of some of the disciplines mentioned, see Van Kerkhove and Van Bendegem (2007). There was a follow-up conference in 2007, whereof the proceedings were published in two volumes: see Van Bendegem et al. (2010) and Van Kerkhove (2009).
} 
as important, so that specific disciplines with this title were created in undergraduate courses and in graduate programs aiming both to educate teachers and researchers in mathematics education.

In 2003 the Work Group 11 (Grupo de Trabalho GT-11) on the Philosophy of Mathematics Education was created in SIPEM-the International Seminar of Research in Mathematics Education that occurs every three years in Brazil. The objective of this group is to present and discuss research developed in this area of investigation.

The SIPEM is an important event in Brazil. It is supported by the Brazilian Society of Mathematics Education-SBEM, and brings together researchers from Brazil and from other countries. It is organized with research groups that focus on specific themes. Researchers submit their articles to the specific Work Group (GT) that they understand to be the most appropriate for discussing their research. Papers are submitted for evaluation by researchers nominated by the Organizing Committee of the event on the basis that they are considered scientifically able to make appropriate and substantiated evaluations of papers and judgements about acceptance. Thus the papers presented in the GTs are evaluated beforehand. GT 11 addresses the Philosophy of Mathematics Education and it was constituted in the II SIPEM, in 2003. For acceptance it was constituted as having a research orientation that transcends the modus operandi of searching in Mathematics Education, as well as the modus operandi of proposing didactic-pedagogical practices for its teaching and learning process. Its way of thinking is characterized as systematic, and it is characterized by its concern with the epistemological, ontological and axiological aspects of issues of mathematics education and in their respective investigative procedures. Besides that, it focuses on and critically analyses world conceptions and ideological visions that such practices and procedures bring with them.

Analysing the history of GT 11 indicates the assiduity of its members in participating in various conferences, including SIPEM (II, III, IV, V) and in sessions of ENEM-National Meeting of Mathematics Education (VII, VIII, IX and X). The number of members attending the meetings has generally been increasing: VII ENEM, Rio de Janeiro 2001 (9 participants); II SIPEM, Santos city 2003 (10 participants); VIII ENEM, Recife 2004 (5 participants); III SIPEM, Águas de Lindóia 2006 (10 participants); IV SIPEM, Brasília 2009 (17 participants); X ENEM, Salvador 2010 (19 participants): V SIPEM, Petrópolis 2012 (20 participants). In addition, the participants come from various Universities across Brazil. This breadth of background facilitates the take up and deepening of the matters discussed. There is a core group of researchers who have participated in all GTs of philosophy of mathematics education since 2001, when it was constituted with that name. This core of researchers, strengthening since SIPEM 2006, enables the continuing discussions progressing from one SIPEM to the next. So the researchers work on the topics that were raised, as well developing investigations that trigger articles and other methods of research. Generally the number of participants of the GT of philosophy of mathematics education varies from 10 to 18 , 
and the papers presented are based on completed research projects. The GT practice is to analyse and to debate each paper.

Another significant aspect revealed in the GT 11 of SIPEM is the power of the scientific debates within this group, with different styles of research conducted, as well as the diverse concepts and themes studied. The papers are mainly phenomenological, drawing on authors such as Edmund Husserl, Wittgenstein, Deleuze and Foucault. The discussions within the group are not characterised by dogmatic attitudes sustaining positions presented as correct, but are rather more open, based on questioning and attempts to understand the presentations, looking for convergence of ideas, the enhancement the field, or enlightenment of the subjects discussed.

An analysis of work produced and published in Brazil in this strand of the philosophy of mathematics education reveals that the movement of discourse construction of the text is through questions that the authors pose to themselves when they become aware about the positivity of their statements. We do not refer here to the questions or interrogations of research, assumed as the motto impeller that triggers the research, but those that are implemented in the dialogue of authors with themselves and with the text that they are architecting. This manner of proceeding is an important tool of philosophical thinking to avoid naturalizing assumptions. Instead, the statements are accompanied by arguments that expand possible understandings and expose the debates that occur in the dialogues mentioned. Description is also revealed as an aspect characterizing philosophical work of philosophy of mathematics education. Descriptions are reports which in the analysed texts provide the ideas of references to works that show themselves relevant to the content of the focused documents analysed, or reports of experiences of significant individuals focussing on the phenomena or complex situations experienced in specific instances and occurrences. They offer differing nuances when the work is developed using phenomenological methods, reporting the experiences of individuals engaged with the phenomenon under study; or ways of mapping, describing complex situations that are experienced in the movement of located existence; or even documents analysed hermeneutically to provide the descriptions mentioned above so that the reader becomes aware of varying interpretations; or also of important ideas in the literature in the treatment of the issue, showing what is said, so that the researcher is able develop accounts and articulations. The essay turns out to be close to the above mentioned investigative procedure, since the writing is articulated in terms of sustained ideas in the explanation of interpretative readings of relevant authors, from the standpoint of education, philosophy and the subject itself, articulating what was understood in new ideas. In this respect the essay shows itself variously nuanced, since the poetical appears and exhibits itself alongside the speech presented in the text.

In the work on philosophy of mathematics education in Brazil there has been diversity of references used by the authors in presenting their papers, but the articles reveal a common method, which involves continually problematizing and interrogating the text that is being written; describing the living experience and the way in which ideas are articulated; and gathering ideas of significant authors around a 
theme under investigation. This work exhibits a constancy with respect to methodological concerns, since they explain the investigated subject, how it comes in terms of building ideas and not only data collection, as well as explaining the authors' ideas that the research utilizes and develops.

In Brazil, research within this strand in the philosophy of education constantly problematizes its assertions, so as not to take them in a natural, fixed or given way. The investigations indicate understandings or syntheses that moving away from having an interrogated or questioned text explained entirely, aiming to clarify the theme under investigation, instead of trying to fully explain it.

For an account of this research in the philosophy of mathematics education in Brazil see Bicudo (2010a, b) and Bicudo and Garnica (2001). This school has also contributed to research in ethnomathematics, see for example, Miarka and Bicudo (2012).

\section{Summary and Looking Ahead}

This publication provides a brief and selective overview of the philosophy of mathematics education. It includes an interpretation of what makes up the philosophy of mathematics education, what it means, what questions it asks and answers, and its overall importance and use. It also provides an authoritative overview of critical mathematics education, a central strand in philosophy of mathematics education research. The philosophy of mathematics has always been of central importance in philosophy of mathematics education research, and an overview of the most relevant modern movements in the philosophy of mathematics is provided, including the emerging philosophy of mathematical practice movement. Some key references to the literature in all of these areas are listed, including publications treating philosophical aspects of ethnomathematics. The home of ethnomathematics research is Brazil, and this survey also gives an overview of another but different strand of research in the philosophy of mathematics education that is emerging there. For Brazil has a very active research community in the philosophy of mathematics education drawing on the Hermeneutic tradition, and developments within this strand are sketched. This provides a case study of a research community in the philosophy of mathematics education in terms of its organisation, theoretical basis and research orientation.

Given the variety and vigour of contributions to the field, the breadth of problems it addresses and the varying research methodologies and methods it employs, the future growth of the field seems guaranteed. Even if it only attends to the 'hygiene' of research in mathematics education, through revealing hidden assumptions within the concepts and methods of research and practice, its future would be guaranteed. But as this short overview illustrates, the philosophy of mathematics education provides a much greater contribution to research in mathematics education than just this. 
Open Access This chapter is distributed under the terms of the Creative Commons Attribution 4.0 International License (http://creativecommons.org/licenses/by/4.0/), which permits use, duplication, adaptation, distribution, and reproduction in any medium or format, as long as you give appropriate credit to the original author(s) and the source, a link is provided to the Creative Commons license, and any changes made are indicated.

The images or other third party material in this chapter are included in the work's Creative Commons license, unless indicated otherwise in the credit line; if such material is not included in the work's Creative Commons license and the respective action is not permitted by statutory regulation, users will need to obtain permission from the license holder to duplicate, adapt or reproduce the material.

\section{References}

Alrø, H., \& Skovsmose, O. (2002). Dialogue and learning in mathematics education: Intention, reflection, critique. Dordrecht: Kluwer Academic Publishers.

Alrø, H., Ravn, O., \& Valero, P. (Eds.). (2010). Critical mathematics education: Past, present, and future. Rotterdam: Sense.

Aspray, W., \& Kitcher, P. (Eds.). (1988). History and philosophy of modern mathematics. Minneapolis: University of Minnesota Press.

Bicudo, M. A. V. (Ed.). (2010a). Filosofia da Educação Matemática. Fenomenologia, concepções, possibilidades didático-pedagógicas. São Paulo: Editora UNESP.

Bicudo, M. A. V. (2010b). Research on mathematics education. ZDM, 42, 325-336.

Bicudo, M. A. V., \& Garnica, A. V. M. (2001). Filosofia da Educação Matemática. Belo Horizonte: Autêntica.

Biotto Filho, D. (2015). Quem não sonhou em ser um jogador de futebol? Trabalho com projetos para reelaborar foregrounds. 2015. Doctoral thesis. Teses. Rio Claro: Universidade Estadual Paulista Júlio de Mesquita Filho.

Bishop, A. (1988). Mathematical enculturation. Dordrecht: Kluwer.

Bloor, D. (1976). Knowledge and social imagery. London, Boston: Routledge \& K. Paul.

Brown, S. I. (1995). Philosophy of mathematics education: POM(E), PO(ME) OR POE(M)?, Philosophy of mathematics education newsletter, No. 8 (May 1995): 16-18. Retrieved from http://socialsciences.exeter.ac.uk/education/research/centres/stem/publications/pmej/.

Chronaki, A. (2010). Revisiting mathemacy: A process-reading of critical mathematics education. In H. Alrø, O. Ravn, \& P. Valero (Eds.), Critical mathematics education: Past, present and future (pp. 31-49). Rotterdam: Sense.

D'Ambrosio, U. (1985). Ethnomathematics and its place in the history and pedagogy of mathematics. For the learning of mathematics, 5(1), 44-48.

D'Ambrosio, U. (1998). Literacy, matheracy and technoracy: The new trivium for the era of technology. Paulo Freire memorial lecture delivered at the first mathematics education and society conference, Nottingham, UK, September 5-12, 1998.

D'Ambrosio, U. (2006). Ethnomathematics: Link between traditions and modernity. Rotterdam: Sense Publishers.

Dehaene, S., \& Brannon, E. (Eds.). (2011). Space, time and number in the brain. Searching for the foundations of mathematical thought. New York: Academic Press.

Ernest, P. (1991) The philosophy of mathematics education, London: Routledge.

Ernest, P. (1998). Social constructivism as a philosophy of mathematics. Albany, New York: State University of New York Press. 
Ernest, P. (2010). The scope and limits of critical mathematics education. In H. Alrø, O. Ravn \& Valero (Eds.), Critical mathematics education: Past, present, and future (pp. 65-87). Rotterdam: Sense.

Ernest, P. (2012). What is our first philosophy in mathematics education? For the Learning of Mathematics, 32(3), 8-14.

Ernest, P. (2013). Values and mathematics: Overt and covert, paper presented at mathematical cultures 2, London, 17-19 September 2013. Revised version in Culture and dialogue, 4(1) (special issue Culture, Science and Dialogue, Guest Editor: M. Ovens).

Ernest, P. (2014). The philosophy of mathematics education: Stephen Lerman's contributions. In P. Gates \& R. Jorgensen (Eds.), Shifts in the field of mathematics education, Stephen Lerman and the turn to the social (pp. 203-213). Singapore: Springer-Verlag.

Ernest, P. (2015). Mathematics and beauty, Mathematics Teaching (pp. 23-27). September 2015.

Ernest, P. (in press). The unit of analysis in mathematics education: Bridging the political-technical divide?, Accepted by Educational studies in mathematics, June 2014.

Ernest, P., Sriraman, B., \& Ernest, N. (Eds.) (2015). Critical mathematics education: Theory, praxis, and reality. Charlotte, North Carolina, USA: Information Age Publishing.

François, K., \& Van Bendegem, J. P. (Eds.). (2007). Philosophical dimensions in mathematics education. New York: Springer.

Frankenstein, M. (1983). Critical mathematics education: An application of Paulo Freire's epistemology. Journal of Education, 164, 315-339.

Frankenstein, M. (1989). Relearning mathematics: A different third $R$-Radical maths. London: Free Association Books.

Frankenstein, M. (2012). Beyond math content and process: Proposals for underlying aspects of social justice education. In A. A. Wager \& D. W. Stinson (Eds.), Teaching mathematics for social justice: Conversations with mathematics educators (pp. 49-62). USA: NCTM, National Council of Mathematics Teachers.

Greer, B., Mukhopadhyay, S., Powell, A. B., \& Nelson-Barber, S. (Eds.). (2009). Culturally responsive mathematics education. New York: Routledge.

Gutstein, E. (2006). Reading and writing the world with mathematics: Toward a pedagogy for social justice. New York: Routledge.

Hossain, S., Mendick, H. \& Adler, J. (2013). Troubling "understanding mathematics in-depth": Its role in the identity work of student-teachers in England, Educational studies in mathematics, doi:10.1007/s10649-013-9474-6 (online).

Jablonka, E. (2003). Mathematical literacy. In A. J. Bishop, M. A. Clements, C. Keitel, J. Kilpatrick, \& F. K. S. Leung (Eds.), Second international handbook of mathematics education (Vol. 1, pp. 75-102). Dordrecht: Kluwer Academic Publishers.

Kitcher, Philip. (1983). The nature of mathematical knowledge. New York: Oxford University Press.

Knijnik, G. (1996). Exclução e resistência: Educação matemática e legitimidade cultural. Porto Alegre: Artes Médicas.

Lakatos, I. (1976). Proofs and refutations. Cambridge: Cambridge University Press.

Lakoff, G., \& Núñez, R. (2000). Where mathematics comes from. How the Embodied Mind Brings Mathematics into Being. New York: Basic Books.

Lerman, S. (Ed.). (2014). Encyclopedia of mathematics education (pp. 116-120). Dordrecht, Heidelberg, New York, London: Springer.

Llewellyn, A. (2010). Questioning Understanding!?. In U. Gellert, E. Jablonka \& C. Morgan (Eds.), Proceedings of the sixth mathematics education and society conference, 2010 (pp. 348-358, Vol. 2), Berlin: Free University Berlin.

Locke, J. (1975). An essay concerning human understanding, Oxford: The Clarendon Press. (First published 1671).

Maddy, P. (1997). Naturalism in mathematics. Oxford: Clarendon Press.

Mancosu, P. (Ed.). (2008). The philosophy of mathematical practice. Oxford, New York: Oxford University Press. 
Marcone, R. (2015). Deficiencialismo: A invenção da deficiência pela normalidade. Doctoral thesis. Rio Claro (SP): Universidade Estadual Paulista (UNESP).

Martin, D. B. (2009). Mathematics teaching, learning, and liberation in the lives of black children. New York: Routledge.

Mellin-Olsen, S. (1981). Instrumentalism as an educational concept. Educational Studies in Mathematics, 12, 351-367.

Miarka, R., \& Bicudo, M. A. V. (2012). Matemática e/na/ou Etnomatemática? Revista Latinoamericana de Etnomatemática, 5(1), 149-158.

Milani, R. (2015). O processo de aprender a dialogar por futuros professores de matemática com seus alunos no estágio supervisionado. Doctoral thesis. Rio Claro (SP): Universidade Estadual Paulista (UNESP).

Pais, A. (2012). A critical approach to equity. In O. Skovsmose \& B. Greer (Eds.), Opening the cage: Critique and politics of mathematics education (pp. 49-92). Rotterdam: Sense Publishers.

Pólya, G. (1945). How to solve it: A new aspect of mathematical method. Princeton: Princeton University Press.

Powell, A. B. (2012). The historical development of criticalmathematics education. In A. A. Wager \& D. W. Stinson (Eds.), Teaching mathematics for social justice: Conversations with mathematics educators (pp. 21-34). USA: NCTM, National Council of Mathematics Teachers.

Powell, A. \& Frankenstein, M. (Eds.). (1997). Ethnomathematics: Challenging Eurocentrism in mathematics education. Albany: State University of New York Press.

Restivo, S. (1985). The Social relations of physics, mysticism, and mathematics. Dordrecht, Boston: D. Reidel.

Restivo, S., Van Bendegem, J. P., \& Fischer, R. (Eds.). (1993) Math worlds: Philosophical and social studies of mathematics and mathematics education. Albany: SUNY Press.

Schwab, J. J. (1961). Education and the structure of the disciplines. In I. Westbury \& N. J. Wilkof (Eds.), Science, curriculum and liberal education: Selected essays of Joseph J. Schwab (pp. 229-272) Chicago: University of Chicago Press, 1978.

Sfard, A. (1998). On two metaphors for learning and the dangers of choosing just one. Educational researcher, 27(2), 4-13. (Mar 1998).

Sinclair, N. (2008). Notes on the aesthetic dimension of mathematics education, paper presented at Conference on first 100 years of ICMI, Rome, 5-8 March 2008. Retrieved on 10 March 2014 at http://www.unige.ch/math/EnsMath/Rome2008/ALL/Papers/SINCL.pdf.

Skemp, R. R. (1976). Relational understanding and instrumental understanding. Mathematics Teaching, 77, 20-26.

Skemp, R. R. (1982). Communicating mathematics: Surface structures and deep structures. Visible Language, 16(3), 281-288.

Skovsmose, O. (1994). Towards a philosophy of critical mathematical education. Dordrecht: Kluwer.

Skovsmose, O. (2001). Educação Matemática Crítica: A Questão da Democracia. Campinas: Papirus.

Skovsmose, O. (2007). Educação Crítica: Incerteza, Matemática, Responsabilidade. São Paulo: Cortez Editora.

Skovsmose, O. (2008). Desafios da Reflexão: Em Educação Matemática Crítica. Campinas: Papirus.

Skovsmose, O. (2009a). In doubt: About language, mathematics, knowledge and life-worlds. Rotterdam: Sense Publishers.

Skovsmose, O. (2009b). Researching possibilities. In M. Setati, R. Vithal, C. Malcolm, \& R. Dhunpath (Eds.), Researching possibilities in mathematics, science and technology education (pp. 105-119). New York: Nova Science Publishers.

Skovsmose, O. (2011a). An invitation to critical mathematics education. Rotterdam: Sense.

Skovsmose, O. (2011b). Critique, generativity, and imagination. For the Learning of Mathematics, 31(3), 19-23. 
Skovsmose, O. (2012). Mathematics as discourse. Bolema (Boletim em Educação Matemática Mathematics Education Bulletin), 26(43), 1-18.

Skovsmose, O. (2014a). Foregrounds: Opaque stories about learning. Rotterdam: Sense Publishers.

Skovsmose, O. (2014b). Critique as uncertainty. Charlotte, North Carolina, USA: Information Age Publishing.

Skovsmose, O. (2014c). Um convite à educação matemática crítica. Campinas, Brazil: Papirus.

Skovsmose, O. (2015a). (Ethno)mathematics as discourse. In C. Bergsten \& B. Sriraman (Eds.), Refractions of mathematics education: Festschrift for Eva Jablonka (155-172) Charlotte, North Carolina, USA: Information Age Publishing. Also published in Bolema, 29(51), 18-37. www.periodicos.rc.biblioteca.unesp.br/index.php/bolema/article/view/9838/6585.

Skovsmose, O. (2015b). An intentionality-interpretation of meaning in mathematics education. Educational Studies in Mathematics, 90(3). Published online: doi:10.1007/s10649-015-9644-9.

Skovsmose, O. (2015c). Mathematics: A critical rationality? In P. Ernest, B. Sriraman and N. Ernest (Eds.), Critical mathematics education: Theory, praxis, and reality (pp. 1-22). Charlotte, North Carolina, USA: Information Age Publishing.

Skovsmose, O., \& Greer, B. (Eds.). (2012). Opening the cage: Critique and politics of mathematics education. Rotterdam: Sense Publishers.

Skovsmose, O., \& Penteado, M. G. (2015). Mathematics education and democracy: An open landscape of tensions, uncertainties, and challenges. In L. D. English \& D. Kirshner (Eds.), Handbook of international research in mathematics education (3rd ed.). New York, NY: Routledge.

Sneed, J. D. (1971). The logical structure of mathematical physics. Dordrecht: Reidel.

Sriraman, B. (Ed.). (2008). International perspectives on social justice in mathematics education. The Montana Mathematics Enthusiast, Monograph 1. Charlotte, NC: Information Age Publishing.

Tymoczko, T. (Ed.). (1986). New directions in the philosophy of mathematics. Boston: Birkhäuser.

Valero, P. (2009). Mathematics education as a network of social practices. Proceedings of CERME 6, January 28th-February 1st 2009. Lyon France (C INRP 2010 www.inrp.fr/editions/cerme6.

Valero, P., \& Skovsmose, O. (Eds.). (2012). Educación Matemática Crítica: Una visión Sociopolítica del Apendizaje y la Enseñanza de las Matemáticas. Bogota: Centro de Investigación y Formación en Educación, Universidad de los Andes; Aalborg: Department of Learning and Philosophy, Aalborg University.

Van Bendegem, J. P. (2014). The impact of the philosophy of mathematical practice on the philosophy of mathematics. In: L. Soler, S. Zwart, M. Lynch \& V. Israel-Jost (Eds.), Science after the practice turn in the philosophy, history, and social studies of science (pp. 215-226). London: Routledge.

Van Bendegem, J. P., De Vuyst, J., \& Van Kerkhove, B. (Eds.). (2010). Philosophical perspectives on mathematical practice. London: College Publications, 2010 (Texts in Philosophy 12).

Van Kerkhove, B. (Ed.). (2009). New perspectives on mathematical practices. Essays in philosophy and history of mathematics. Singapore: World Scientific.

Van Kerkhove, B., \& Van Bendegem, J. P. (Eds.). (2007). Perspectives on mathematical practices: Bringing together philosophy of mathematics, sociology of mathematics, and mathematics education. Dordrecht: Springer.

Vithal, R. (2003). In search of a pedagogy of conflict and dialogue for mathematics education. Dordrecht: Kluwer Academic Publishers.

Wager, A. A., \& Stinson, D. W. (Eds.). (2012). Teaching mathematics for social justice: Conversations with mathematics educators. USA: NCTM, National Council of Mathematics Teachers.

Yasukawa, K., Skovsmose, O., \& Ravn, O. (2015). Scripting the world in mathematics and its ethical implications. In P. Ernest, B. Sriraman, \& N. Ernest (Eds.), Critical mathematics education: Theory, praxis, and reality (pp. 81-99). Charlotte, North Carolina, USA: Information Age Publishing. 


\section{Further Reading}

The following is a list of English language literature suitable for further study in the philosophy of mathematics education, organised by subspecialism. There are extensive literatures in other languages too, such as Danish and Portuguese (as the above reference list shows).

\section{Philosophy of Mathematics Education}

Ernest, P. (1991) The Philosophy of Mathematics Education, London: Routledge.

François, K., \& Van Bendegem, J. P. (Eds.). (2007). Philosophical dimensions in mathematics education. New York: Springer.

Restivo, S., Van Bendegem, J. P., \& Fischer, R. (Eds.). (1993). Math Worlds: Philosophical and social studies of mathematics and mathematics education. Albany: SUNY Press.

Philosophy of Mathematics Education Journal, Nos. 1 (1990) to 29 (2015). Retrieve from http:// socialsciences.exeter.ac.uk/education/research/centres/stem/publications/pmej/.

\section{Critical Mathematics Education}

Alrø, H., Ravn, O., \& Valero, P. (Eds.). (2010). Critical mathematics education: Past, present, and future. Rotterdam: Sense.

Ernest, P., Sriraman, B., \& Ernest, N. (Eds.). (2015). Critical mathematics education: Theory, praxis, and reality. Charlotte, North Carolina, USA: Information Age.

Skovsmose, O. (1994). Towards a philosophy of critical mathematical education. Dordrecht: Kluwer.

Skovsmose, O. (2011). An invitation to critical mathematics education. Rotterdam: Sense.

\section{Ethnomathematics}

D’Ambrosio, U. (2006). Ethnomathematics: Link between traditions and modernity. Rotterdam: Sense.

Powell, A. \& Frankenstein, M. (Eds.). (1997). Ethnomathematics: Challenging Eurocentrism in mathematics education. Albany: State University of New York Press.

\section{Philosophy of Mathematics}

Ernest, P. (1998). Social constructivism as a philosophy of mathematics. Albany, New York: State University of New York Press.

Lakatos, I. (1976). Proofs and refutations. Cambridge: Cambridge University Press.

Van Bendegem, J. P., De Vuys, J., \& Van Kerkhove, B. (Eds.). (2010). Philosophical perspectives on mathematical practice. London: College Publications. 